\title{
Investigation of Silver Nitrate on Cytotoxicity and Apoptosis in MCF7 Human Breast Carcinoma Cells
}

\author{
Ayse Kaplan, Hatice Mehtap Kutlu
}

Faculty of Science, Department of Biology, Eskisehir Technical University, Eskisehir, Turkey.

\begin{abstract}
Background: Metal compounds have been studied in vitro for many years and these compounds's effects are shown on tumors. Anticancer potential of silver and silver metal compounds is investigated in these days. A study on the in vitro interactions of silver nitrate $\left(\mathrm{AgNO}_{3}\right)$ with $\mathrm{MCF} 7$ human breast carcinoma cells was performed to detect cytotoxic effects which induce apoptotic pathways. Materials and Methods: The cytotoxicity of silver nitrate which administered on MCF7 cells was assessed by MTT assay. The apoptotic influences of silver nitrate $\left(\mathrm{IC}_{50}\right.$ : inhibition concentration) were determined using Annexin V-FITC/PI, JC-1, TUNEL paraffin embedded and confocal microscopy assays. Silver nitrate induced cytotoxicity and apoptosis in MCF7 cells. Results: In this work, we demonstrated that the inhibition of cell growth which is time and dose dependent in MCF7 cells for 24, 48 and 72 hours. The inhibition concentration of silver nitrate $\left(\mathrm{IC}_{50}\right)$ was found as $10 \mu \mathrm{M}$ in MCF7 cells for 72 hrs. The early/late apoptotic and necrotic changes which occured with silver nitrate $\left(\mathrm{IC}_{50}: 10 \mu \mathrm{M}\right)$ administered, were analyzed in the MCF7 cells for $72 \mathrm{hrs}$. However, the reduced mitochondrial membrane activity $(\Delta \Psi \mathrm{mt})$ was observed by silver nitrate-treated $\left(\mathrm{IC}_{50}: 10 \mu \mathrm{M}\right)$ in the MCF7 cells for $72 \mathrm{hrs}$. In addition to these findings, a variety of apoptotic structures were demonstrated on MCF7 cells for $72 \mathrm{hrs}$. Conclusions: The results suggest that silver nitrate could be attributed as chemotherapeutic agent for medical applications in breast cancer treatment.
\end{abstract}

Keywords: Apoptosis- Breast cancer- Cytotoxicity- Mitochondrial membrane potential- Silver nitrate

Asian Pac J Cancer Biol, 5 (2), 49-56

\section{Introduction}

Breast cancer is one of the most malignant type of cancer among women in United State of America and North West Europe [1-2]. Therefore, we found useful to work on MCF7 human breast carcinoma cells. MCF7 human breast cell line was obtained from metastatic breast cancer patient at 1970 [1].

Metal compounds have been used in medicine for years and shown to be effective on human and animal tumors in vitro [3]. Although there are numerous metal agents with apoptotic/antiproliferative properties used in the treatment of breast cancer, they are known to have side effects and are not efficient. Therefore, this increased interest in the investigation of new metal chemotherapeutic agents against cancer [4]. Lately, silver and silver complexes are investigated on cancer cells [5-6]. Although silver ions are efficient against patogens, they have low toxicity on healthy cells [7-9]. The effects of
Submission Date: 02/17/2020Ａcceptance Date: 05/05/2020

Corresponding Author:

Dr. Ayse Kaplan

Faculty of Science, Department of Biology, Eskisehir Technical University, Eskisehir, Turkey.

Email: aysekaplan26@hotmail.com 
as a result of reduction amount of apoptosis, the cancer development is occured [21]. Mitochondria plays a key role in the apoptotic process. Mitochondrial control of apoptosis has been described at several levels. One of these levels is mitochondrial membrane potential $(\Delta \Psi \mathrm{mt})[22]$.

The aim of current work was to determine the triggered pathways underlying the anticancer effects of silver nitrate against MCF7 breast carcinoma cells. We investigated the apoptotic signal pathways mediated by cytotoxic effects of silver nitrate using Annexin-V FITC/PI, mitochondrial membrane potential assay (JC-1 staining) and TUNEL assay. Morphologically generated apoptotic structures were scanned via confocal microscopy.

\section{Materials and Methods}

\section{Materials}

The MCF7 cells were purchased from American Type Culture Collection (ATCC) (Manassas, VA, USA). Silver nitrate (AgNO3) was purchased from Himedia, India. Roswell Park Memorial Institute medium (RPMI 1640) (Sigma Aldrich, USA), the Fetal Bovine Serum (FBS) (Gibco, South America), the penicillin-streptomycin (Gibco, South America), the Dulbeccos's Phosphate Buffered Saline Concentrate (PBS) (10X) (Biological Industries, Israel), Trypsine/EDTA Solution (Biochrom, Germany), 3-(4,5-Dimethyl-2-thiazolyl)-2,5-diphenyl2H-tetrazolium bromide (MTT) (Alfa aesar, Germany), and the dimethylsulfoxide (DMSO) were maintained from Sigma-Aldrich, USA. Annexin-V FITC/Propidium iodide (PI) apoptosis detection kits were purchased from BD Biosciences, San Diego, USA. The JC1 kit was obtained by BD Biosciences, San Diego, USA. The Annexin-V FITC and acridine orange (Santa Cruz Biotechnology, USA), TUNEL kits were purchased from Santa Cruz Biotechnology, USA. This work was made between January 2014 and March 2014 in Medical Plants, Drugs and Scientific Research Center for cell culture studies at Anadolu University.

\section{Methods}

\section{Cell culture model}

MCF7 human breast carcinoma cells were maintained in $75 \mathrm{~cm}^{2}$ sterile plastic tissue culture flasks in RPMI medium supplemented with $10 \%(\mathrm{v} / \mathrm{v})$ fetal bovine serum and $1 \%$ penicillin/streptomycin at 100 units $/ \mathrm{mL}$ as adherent monolayers. These cells were grown at $37^{\circ} \mathrm{C}$ humidified atmosphere containing $5 \% \mathrm{CO}_{2}$ in air.

\section{Cell survival assay}

To investigate the cytotoxic effects of silver nitrate, MTT (3-(4,5-dimethylthiazol-2-yl)-2,5-diphenyl tetrazolium) assay was used. MCF7 human breast cancer cells were seeded into each well of 96 plate at a density of 10.000 cells. Silver nitrate (AgNO3) was administered in increasing doses (1.9 - 3.9 - 7.8 - 15.6 - 31.25 - 62.5 - 125 $-250-500-1000 \mu \mathrm{M})$ on MCF7 cells and incubated for 24,48 ve 72 hours. The main stock solution of silver nitrate was prepared in DMSO and medium. The silver nitrate was dissolved in DMSO and diluted with medium. Following incubation, the MTT solution prepared in PBS was added to each well as $20 \mu \mathrm{l}$ and kept for 2-4 hrs. Then, the medium was removed and $100 \mu \mathrm{DMSO}$ was added to each well, dissolving the sediment for 10 minutes. The cells were measured at $540 \mathrm{~nm}$ using microtitre plate reader (Bio. Tec. ELx808IU, USA). The cell viability was calculated as a percent ratio and compared with control cells. Each concentration was repeated in three wells and $\mathrm{IC}_{50}$ values were defined as the drug concentrations that reduced absorbance to $50 \%$ of control values. Three independent experiments were conducted in order to obtain the proper $\mathrm{IC}_{50}$ value.

\section{Annexin V-FITC/ PI staining}

The number of apoptotic/necrotic cells was measured using Annexin V/PI (propidium iodide) assay. MCF7 cells were seeded 6 well plates at a concentration of $1 \times 10^{5}$ cells/ well with RPMI 1640 supplemented with 10\% FBS and $1 \%$ penicillin-streptomycin. The inhibition concentration of the silver nitrate $\left(\mathrm{IC}_{50}: 10 \mu \mathrm{M}\right)$ was added on MCF7 cells. The plates were incubated at $37^{\circ} \mathrm{C}$ in an atmosphere of $5 \% \mathrm{CO}_{2}$ for $72 \mathrm{hr}$. After the incubation, the cells were trypsinized and centrifuged, and the cell pellets were twice resuspended in phosphate-buffered saline (PBS). Then, the $100 \mu$ Binding Buffer solution (0.1 M Hepes/NaOH (pH 7.4), 1.4 M NaCl, $25 \mathrm{mM} \mathrm{CaCl}$ ) (BD Pharmingen, San Diego, USA) was added to each sample, and the cells were marked with Annexin V-FITC $(5 \mu \mathrm{g} / \mathrm{mL})$ and PI (propidium iodide) $(5 \mu \mathrm{g} / \mathrm{mL})$ for 15 minutes in the dark at room temperature $\left(20-25^{\circ} \mathrm{C}\right)$. The data were collected for 10.000 cells in each sample. The samples were analyzed by the BD FACS Aria (I) Cell Sorter, and Diva Software flow cytometry.

\section{JC-1 labelling}

The mitochondrial membrane potential was measured using JC-1 (5',6,6'-tetrachloro-1,1', ,3,3' -tetraethylbenzimidazolylcarbocyanine iodide) dye. MCF7 cells were seeded in six-well plates at a density of $10^{5}$ cells $/ \mathrm{ml}$, and the $\mathrm{IC}_{50}$ dose of silver nitrate $(10 \mu \mathrm{M})$ was added to cells. The cells were incubated $5 \% \mathrm{CO}_{2}$ air-conditioned atmosphere at $37{ }^{\circ} \mathrm{C}$ temperature. Following 72 hours incubation, the cells were trypsinized, washed with PBS, and centrifuged $400 \times \mathrm{g}$ for 5 minutes. JC1 dye solution (1X assay buffer $+\mathrm{JC} 1$ stock solution) was added on the cells. The JC1 stock solution was prepared by dissolving the DMSO. Thereafter, the samples were incubated at a temperature of $37{ }^{\circ} \mathrm{C}$ for $10-15 \mathrm{~min}$. After incubation, the cells were washed twice with an assay buffer, and read by the BD FACS Aria (I) Cell Sorter Diva Software flow cytometry.

\section{TUNEL paraffin-embedded assay}

TUNEL paraffin-embedded assay was preferred to determine the DNA strand breakages. The MCF7 human breast cells were maintained in $75 \mathrm{~cm}^{2}$ sterile plastic tissue culture flasks in RPMI medium supplemented with $10 \%$ (v/v) fetal bovine serum and 1\% penicillin/streptomycin 
at 100 units/mL as adherent monolayers. After that, the $\mathrm{IC}_{50}$ concentration of silver nitrate $(10 \mu \mathrm{M})$ was added on cells for $72 \mathrm{hr}$. Following that incubation, the cells in flask were collected in eppendorf tubes. The cells were fixed $10 \%$ formaldehyde (neutral-buffered) $(900 \mathrm{ml}$ distilled water ( $\mathrm{pH} 7$ ), $4 \mathrm{~g}$ sodium phosphate monobasic, $6.5 \mathrm{~g}$ sodium phosphate dibasic, $100 \mathrm{ml}$ of pure formaldehyde). Thereafter, the cells were embedded in paraffin and sectioned in 4 microns thickness. The sections were incubated in $60 \%, 70 \%, 80 \%, 90 \%$ and $96 \%$ alcohols series for $1 \mathrm{hr}$. The sections were reduced with distilled water and exposed to Proteinase K enyzme (in $37^{\circ} \mathrm{C}$ ) for $15 \mathrm{~min}$. Then, they were washed with PBS and incubated in hydrogen peroxide (3\% aqueous). The sections were also incubated in PBS and Equilibration Buffer for 3 min. TdT enzyme working solution was kept for 1 hr. Digoxigenin peroxidase secondary antibody was incubated on sections for $30 \mathrm{~min}$. DAB Chromogen kept for $5 \mathrm{~min}$. After incubation, acetone and xylene were used for half an hour on sections. The sections were incubated three times in paraffin for half an hour.

\section{Confocal microscopy assay}

The apoptotic structures were observed by confocal microscopy. MCF7 cells were plated onto sterilized coverslips in 6 well-plates, and exposed to the $\mathrm{IC}_{50}$ dose of silver nitrate $(10 \mu \mathrm{M})$ for 72 hours at a temperature of $37^{\circ} \mathrm{C}$. After exposure, the control and treated cells were washed with PBS and stained by acridine orange fluorescent dye. Whereupon, the structure of the cell membrane and nucleus morphologically were monitorized and the structural changes were detected. The morphology was scanned by the Leica TCS-SP5 II confocal microscopy and the Leica Confocal Software version 2.00 were used.

\section{Results}

\section{Silver nitrate induced cytotoxicity}

The cytotoxic effects on cell viability of silver nitrate were defined in MCF7 cells using MTT assay (Figure 1). Silver nitrate induced cytotoxicity in MCF7 cells. The cytotoxicity increased depending on time and dose (Figure 1). The $\mathrm{IC}_{50}$ concentration of silver nitrate on MCF7 cells was assigned as $10 \mu \mathrm{M}$ at $72 \mathrm{hr}$. Figure 1 shows that the number of living cells decreased almost $40 \%$ in the lowest dose $1.9 \mu \mathrm{M}$ at $72 \mathrm{hr}$. The highest dose $1000 \mu \mathrm{M}$ caused to $92 \%$ reduced on cells for $72 \mathrm{hr}$. Based on these results, we determined silver nitrate $\mathrm{IC}_{50}$ dose for other apoptosis analyzes. These values were calculated using SPSS software and Microsoft Excel 2010. This experiment was repeated 3 times.

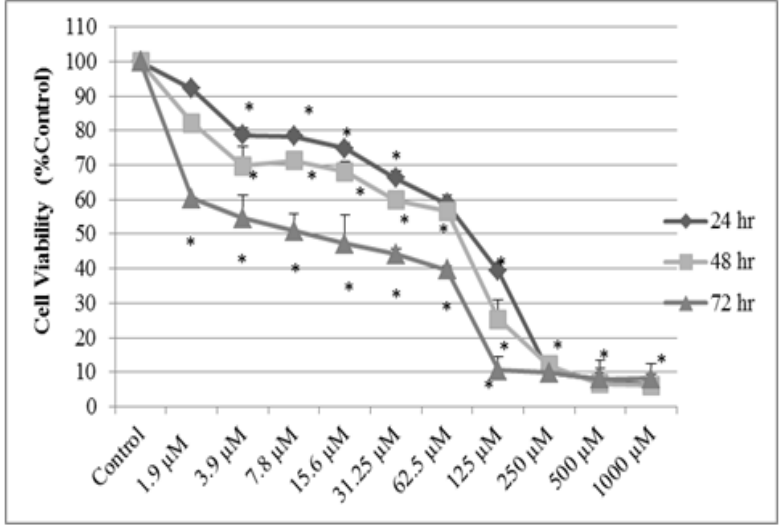

Figure 1. The Cytotoxic Effects of Silver Nitrate on Cell Growth were Detected using MTT Assay at Various Concentrations $(1.9-3.9-7.8-15.6-31.2-62.5-$ $125-250 \mu \mathrm{M} / \mathrm{mL}$ ) on MCF7 cells for 24,48 and 72 hours. Silver nitrate inhibited cell growth as time and dose dependent for 24, 48 and 72 hrs in MCF7 cells. (*) sign shows significant differences compared to control. Significance value is $p<0,05$. Data recorded as mean \pm SD.

The cells positive of apoptosis and necrosis were triggered by silver nitrate

In order to detect the ratio of early/late apoptotic and necrotic cell death induced by silver nitrate $\left(\mathrm{AgNO}_{3}\right)$, the cells were labelled by Annexin V and PI (Figure 2). Apoptotic cells are stained by Annexin V and PI determines necrotic cells as a result of damaged cell membrane compare to control. Early apoptotic cells increased as $23 \%$. There was not a significant increase in necrotic and late apoptotic cells (Table 1).

\section{The mitochondrial membrane was depolarized by silver} nitrate

The changes in mitochondrial membrane potential $(\Delta \Psi \mathrm{mt})$ that occur during apoptosis were determined using JC-1 fluorochrome dye $\left(5,5^{\prime}, 6,6^{\prime}\right.$-tetrachloro-1, $1^{\prime}, 3,3^{\prime}$ tetraethylbenzimidazolcarbocyanine iodide). A reduced $\Delta \Psi \mathrm{mt}$ was observed in response to $\mathrm{IC}_{50}$ dose of silver nitrate $(10 \mu \mathrm{M})$ (Figure 3$)$. Compared to control cells, the mitochondrial membrane potential $(\Delta \Psi \mathrm{mt})$ decreased approximately 3 -fold after administration of silver nitrate for $72 \mathrm{hr}$ (Table 2).

\section{The silver nitrate treatment and TUNEL assay}

We performed TUNEL (terminal deoxynucleotidyl transferase [TdT]- mediated deoxyuridinetriphosphate [dUTP] nick endlabeling) paraffin embedded to analyse breaks of DNA strand. Silver nitrate caused DNA breaks on MCF7 cells (Figure 4c-d). These breaks of DNA strand

Table 1. The Detection of Early/late Apoptotic and Necrotic Numbers by Silver Nitrate $\left(\mathrm{IC}_{50}: 10 \mu \mathrm{M}\right)$ Administered on MCF7 Cells for $72 \mathrm{hr}$.

\begin{tabular}{lllll}
\hline Annexin V-FITC/PI staining & Q1 & Q2 & Q3 & Q4 \\
\hline Control (\%) & 5.6 & 3.6 & 90.2 & 0.7 \\
Silver nitrate (\%) & 0.2 & 4.0 & 72.7 & 23.1 \\
\hline
\end{tabular}

Q1, Necrosis; Q2, Late apoptosis; Q3, Viability; Q4, Early apoptosis 


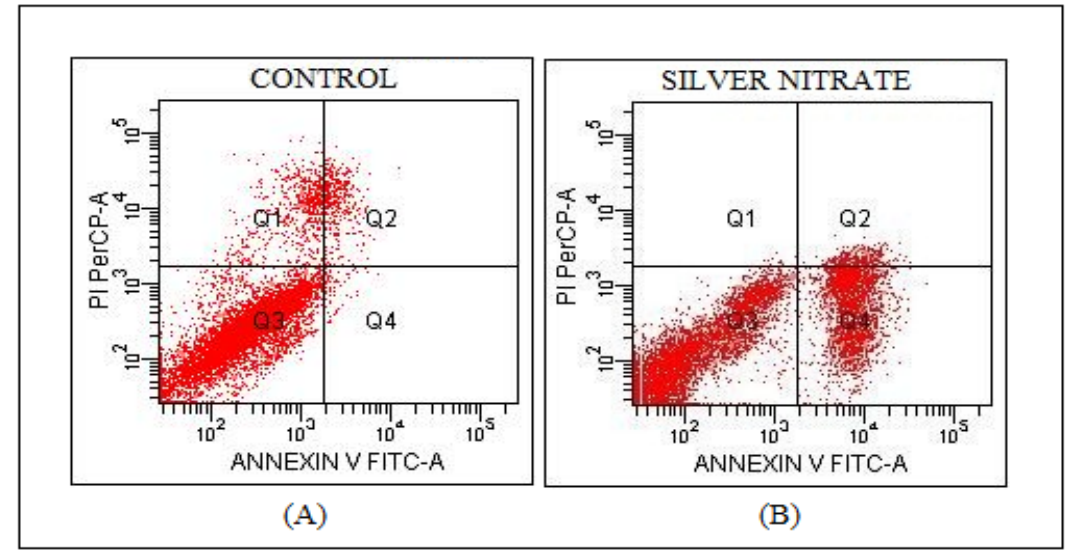

Figure. 2 Annexin-V FITC and PI Staining of MCF7 Cells to Assay Early/late Apoptosis and Necrosis Induced by the Concentration of Silver Nitrate $\left(\mathrm{IC}_{50}, 10 \mu \mathrm{M}\right)$ for $72 \mathrm{hr}$; (A) Control (B) MCF7 Cells were Treated with the Concentration of Silver Nitrate $\left(\mathrm{IC}_{50}, 10 \mu \mathrm{M}\right)$ for $72 \mathrm{hr}$. The early apoptotic cells increased significantly $23 \%$ compare to control cells $(\mathrm{Q} 1=$ Necrosis, Q2=Late apoptosis, Q3=Viability, Q4=Early apoptosis). At least 10,000 cells were analyzed per sample, and quadrant analysis was performed.

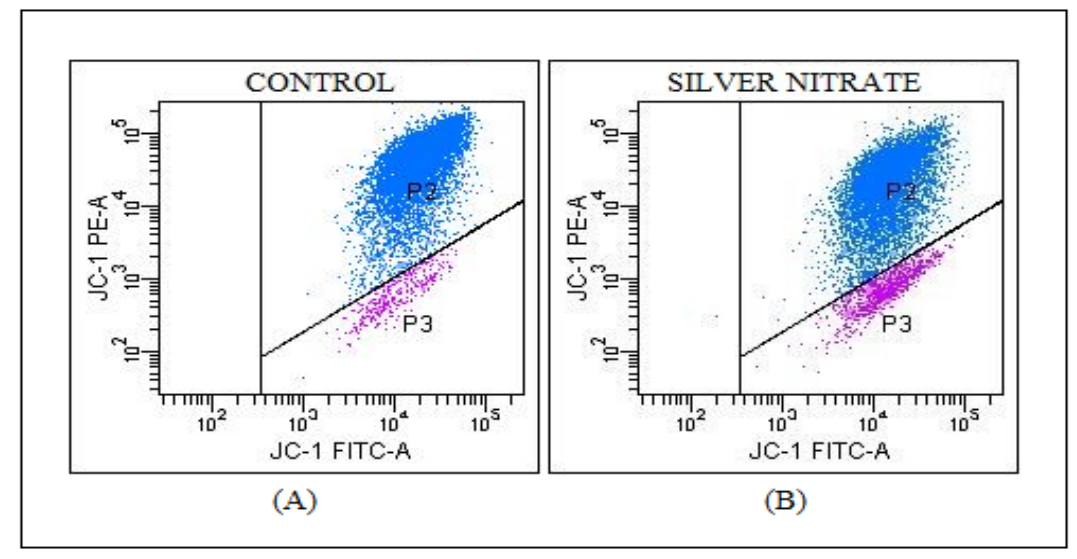

Figure 3. The Reduction in Mitochondrial Membrane Potential was Assessed by JC-1 Staining. A) The untreated MCF7 cells. B) The treated MCF7 cells with silver nitrate. The mitochondrial membrane potential decreased approximately 3-fold compare to control cells for $72 \mathrm{~h}$. P2, The cells with polarized mitochondrial membrane potential. P3, The cells with depolarized mitochondrial membrane potential. At least 10,000 cells were analyzed per sample, and quadrant analysis was performed

were stained with dark brown compared with control MCF7 cells (Figure 4a-b).

The morphological assay of MCF7 cells treated with silver nitrate

The morphological assay of MCF7 cells treated with silver nitrate $\left(\mathrm{IC}_{50}\right.$ value: $\left.10 \mu \mathrm{M}\right)$ was conducted through confocal microscopic evaluation. We investigated the apoptotic effect of silver nitrate $\left(\mathrm{IC}_{50}: 10 \mu \mathrm{M}\right)$ on MCF7 cells. We detected by the appearance of apoptotic

Table 2. The Efficacy of Silver Nitrate $\left(\mathrm{IC}_{50}: 10 \mu \mathrm{M}\right)$ on Mitochondrial Membrane Potential of MCF7 Cells for $72 \mathrm{hr}$

\begin{tabular}{lcc}
\hline JC-1 labelling & P2 & P3 \\
\hline Control (\%) & 96.5 & 3.5 \\
Silver nitrate (\%) & 90.6 & 9.5
\end{tabular}

P2, The cells with polarized mitochondrial membrane potential. P3, The cells with depolarized mitochondrial membrane potential. bodies. The apoptotic structures of silver nitrate-treated MCF7 cells were determined at $72 \mathrm{hr}$ by confocal microscopy. The morphological changes were recorded as nucleus condensation, ghost cells and fragmented DNA (Figure 5d-e-f).

\section{Discussion}

Our studies suggest that silver nitrate increased cytotoxicity and apoptotic effects on MCF7 cells. Consequently, the administered silver nitrate on MCF7 cells significantly reduced cell growth and was cytotoxic effective at low doses, indicating that apoptotic pathways. In addition, silver nitrate increased depolarized mitochondrial membrane potential. The depolarized mitochondrial membrane potential is an important factor at signal pathways leading to apoptosis. Finally, silver nitrate induced the early/late apoptosis and necrosis in MCF7 cells and the main cause of cell death was determined as early apoptosis. The early apoptosis was 


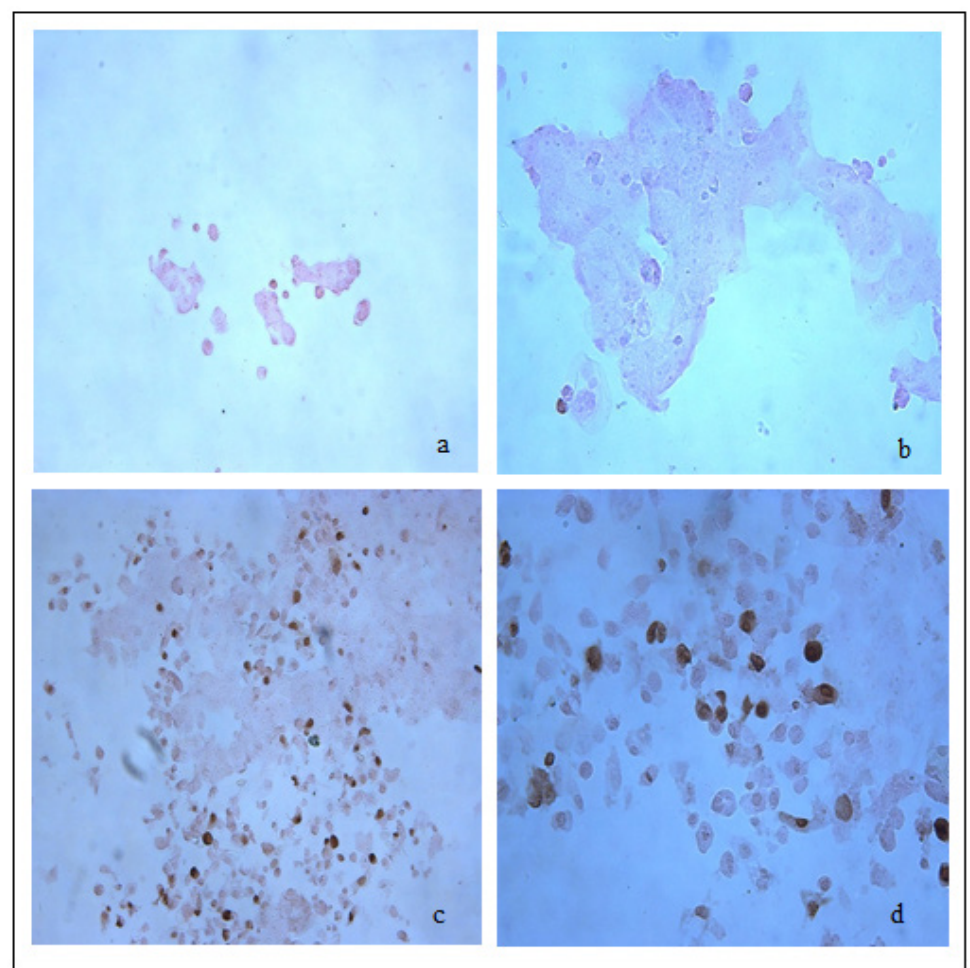

Figure 4. The TUNEL Paraffin-embedded Assay. The light microscope was used for imaging. The apoptotic effect (DNA fragmentation) of silver nitrate on MCF7 cells. (a-b) No staining: in the absence of pretreatment there is no TUNEL access to DNA breaks. $(20 \times$ and $40 \times)$. (c-d) The $\mathrm{IC}_{50}$ concentration $(10 \mu \mathrm{M})$ of silver nitrate for 72 hour was used on MCF7 cells $(20 \times$ and $40 \times)$. The apoptotic nuclei were stain dark brown. The brown nuclei are indicated by the black arrow.

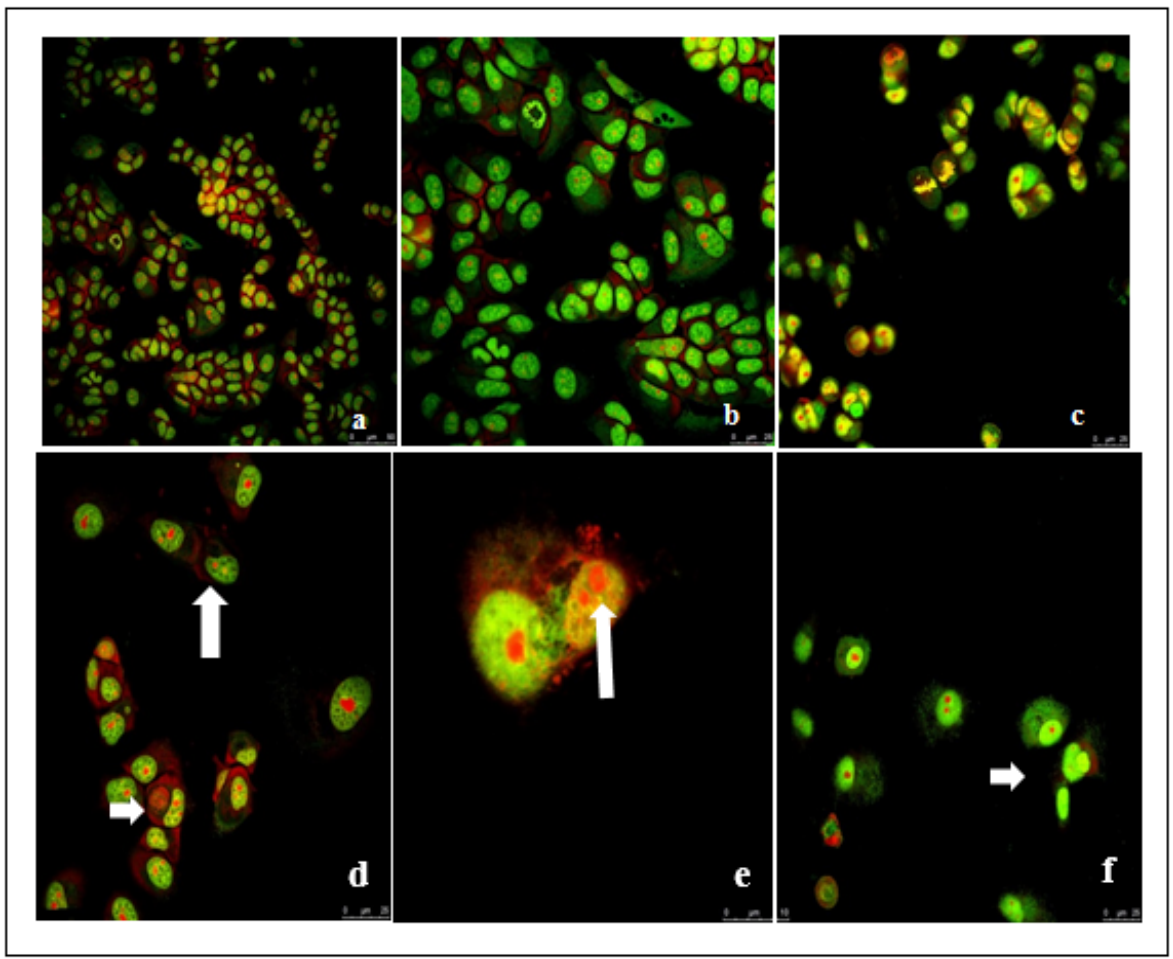

Figure 5. Confocal Microscopy Assay. The cells were stained by acridine orange. a-b-c) the nucleus of untreated cells. $\mathrm{d}-\mathrm{e}-\mathrm{f})$ the nucleus of treated cells with silver nitrate $\left(\mathrm{IC}_{50}: 10 \mu \mathrm{M}\right)$. The apoptotic bodies were showed by arrows. 
$19 \%$ more activity than late apoptosis and necrosis.

For the past 20 years, silver compounds, particularly silver nitrate, has been used intensely in antimicrobial treatment [10-11]. The dilute solutions of silver nitrate have been used to prevent bacteria in newborn babies' eyes. It has been administered in the treatment of extensive burns and has been used in the treatment of many diseases such as ulcers and wart [23]. The reports indicate that silver compounds have in vitro anticancer activity in last years. In these days, researchers have focused on silver nitrate from silver compound and have shown to trigger apoptosis [8]. Silver nitrate has been tested in immortalized murine fibroblast cell line L929 and the cytotoxic effects have been observed [24]. Park et al have demonstrated that silver nitrate increased cytotoxic activity and $\mathrm{IC}_{20}$ value of silver nitrate has found as $7.1 \mu \mathrm{g} / \mathrm{ml}$ in L929 cells for 24 $\mathrm{hr}$ [25]. In present study, $\mathrm{IC}_{20}$ value of silver nitrate was found as $130 \mu \mathrm{M}$ in MCF7 cells. Kaba and Egorova (2015) have suggested that silver nitrate has been less cytotoxic toward U937 (human leukemic monocyte lymphoma cell line) at various concentrations [26]. In another work, the different concentrations of silver nitrate (1-10-50-100 $\mu \mathrm{g})$ have been used to study the viability of MDA-MB-231 cells and the toxicity has been measured. The silver nitrate has treated cancer cells and it has been observed more than $60 \%$ viable cells at $100 \mu \mathrm{g} / \mathrm{ml}$ concentration [27]. In our study, it was determined $8 \%$ viable cells at highest concentration of silver nitrate $(1000 \mu \mathrm{M})$ (Figure 1). Silver nitrate $\left(\mathrm{AgNO}_{3}\right)$ has administered on OVCAR-3 (ovarian), MB157 (breast) ve Hela (cervikal) human cancer cell lines and the inhibition effects of silver nitrate $\left(\mathrm{IC}_{50}\right.$ value $)$ have been obtained respectively in $35 \mu \mathrm{M}, 5 \mu \mathrm{M}$ and $50 \mu \mathrm{M}$ for 72 hours. Consequently, the silver nitrate has been observed most effective in MB157 cell line compared to OVCAR-3 and Hela cell lines due to ultra low dose $(5 \mu \mathrm{M})$ as $\mathrm{IC}_{50}$ value [5]. Our results showed that $\mathrm{IC}_{50}$ value of silver nitrate was obtained as $10 \mu \mathrm{M}$ in MCF7 cell lines. This means that silver nitrate is more effective on MCF7 cells compare to Hela and OVCAR-3 cells. But it is not as effective as in MB157 cells. These findings indicate that silver nitrate shows different effects in various cells. Miura and Shinohara (2009) have showed that silver nitrate has powerful cytotoxic influences on Hela cell lines and has triggered apoptosis as a result of the oxidative stress. The inhibition value of silver nitrate $\left(\mathrm{IC}_{50}\right)$ has been detected as $17 \mu \mathrm{g}$ in Hela cells. The early/ late apoptotic effects of silver nitrate have been analyzed as increased dose dependent. The late apoptosis has increased compare to early apoptosis in Hela cells [28]. Our findings demonstrated that early apoptosis increased more than late apoptosis in MCF7 cells (Figure 2). This indicates that silver nitrate has different apoptotic effects on dissimilar cells. Our results show that it has been occured less necrosis according to Miura and Shinohara findings. In another study, The lowest concentration effect of silver nitrate has been detected as $30 \mu \mathrm{M}$ for $24 \mathrm{hrs}$. Silver nitrate has inhibited cell growth in A549 adenocarcinoma human lung cells [29]. In our study, the lowest concentration value is $7.8-15.6 \mu \mathrm{M}$ for $24 \mathrm{hrs}$. This result shows that silver nitrate has more effective on MCF7 cells compared to A549 cells.

Foldbjerg et al (2011) have revealed that silver ions induced apoptotic DNA damage by increased ROS (reactive oxygen species) levels in A549 cells [30]. In a study, silver ions has triggered apoptosis by promoting cellular mitochondrial damage in human promyelocytic leukemic HL-60 cells [31]. A group of investigators have examined 6 and 24 hour effects of silver nitrate on MCF7 cells and observed that they caused oxidative stress on cells with a dose of 1.5 micrograms / $\mathrm{ml}$ [32]. We worked silver nitrate by a wide dose (1.9-1000 micromolar) and time interval $(24,48$ and 72 hour) on MCF7 cells. We revealed that silver nitrate induced apoptosis by depending on depolarized mitochondrial membrane potential in MCF7 cells (Figure 3 and Table 2). In another our work, we studied gene analyses and apoptotic effects of silver nitrate in A549 cells. Our findings revealed that the proportion of apoptotic cells was increased by silver nitrate in A549 cells. Our data on the gene level obtained by microarray analysis showed that silver nitrate induced apoptosis by a caspase-independent pathway [33]. We also examined the cytotoxic, antiproliferative and apoptotic effects of silver nitrate in h-ras transformed 5RP7 cells. We observed that it caused apoptotic effects on these cells at low doses and that it was activated by activating caspase-3. We also sighted that no toxic effect on healthy NIH3T3 cells at low-doses [34].

$\mathrm{HaCaT}$ keratinocytes and K562 erythroleukemia mammalian cell lines have been exposed to various concentrations of silver nitrate and it has been effective respectively at 6.4 and $3.5 \mu \mathrm{M}$ doses as $\mathrm{IC}_{50}$ values. These values are similar to the our results. After silver nitrate administered at low doses $(<1 \mu \mathrm{M})$, chromatin changes have been observed on K562 cells. The nuclear changes such as condensed chromatin have occured by silver nitrate. The concentrations of silver nitrate (10-15 $\mu \mathrm{M})$ have caused nuclear shrinking with an infrequent formation of apoptotic bodies [35]. In another work, fluorescent microscopic images have showed that the silver nitrate has caused apoptotic bodies in MDA-MB-231 human breast cancer cells [27]. The our work reported that the inhibition concentration of silver nitrate $\left(\mathrm{IC}_{50}: 10 \mu \mathrm{M}\right)$ created condensed nuclear, fragmented DNA and various apoptotic bodies (Figure 5d-e-f).

In another work, it has been analyzed cytotoxicity of silver nitrate on normal cell line (GES-1) and BEL-7404 (human hepatoma cells), A549 (human non-small cell lung cancer), HepG2 (human hepatoma cells), NCI-H1650 (human non-small cell lung cancer cells) cell line and, it has exhibited excellent anticancer activity after a 48 $\mathrm{h}$ treatment. The $\mathrm{IC}_{50}$ values of $\mathrm{AgNO}_{3}$ are respectively $38.67 \mu \mathrm{g} / \mathrm{mL}, 22.42 \mu \mathrm{g} / \mathrm{mL}, 33.824 \mu \mathrm{g} / \mathrm{mL}, 5.363 \mu \mathrm{g} / \mathrm{mL}$ and $29.949 \mu \mathrm{g} / \mathrm{mL}$ [36]. Silver nitrate has been tested for cytotoxic activities against A2780 ovarian cancer cells and, $\mathrm{IC}_{50}$ of silver nitrate has been found as $16.1 \mu \mathrm{M}$ [37]. In our study, it has been found as $10 \mu \mathrm{M}$ on MCF7 cells. This indicates that it has higher anticancer effect on MCF7 cells. Silver nitrate has treated with increasing concentrations of the compounds $(0.01-10 \mu \mathrm{M})$ for $72 \mathrm{~h}$ on B16F10 (metastatic murine melanoma) cells 
and on Melan-a (non-tumorigenic murine melanocyte) cells and cell viability has been determined by the MTT colorimetric assay. Silver nitrate has been less active than cisplatin on non-malignant Melan-a cells, indicating that it might promote less damage on normal cells, which is an important characteristic of new anticancer drug candidates [38]. It has been found that $\mathrm{Ag}$ ions alone at $20 \mu \mathrm{M}$ decreased cell viability of A549 cells by $\sim 80 \%$, but no cytotoxicity has been seen at doses less than $10 \mu \mathrm{M}$ [39]. Silver nitrate has been assessed cytotoxicity by MTT, neutral red uptake (NRU), total protein content (TPC) and leakage lactate dehydrogenase (LDH) assays on Balb/c 3T3 and HepG2 human liver cancer cells. Inhibitory concentrations $\left(\mathrm{IC}_{50}, \mu \mathrm{M}\right)$ of silver nitrate have been determined as $2.13 \pm 0.88$ in Balb/c 3T3 and $6.48 \pm 1.60$ in HepG2 cells by MTT assay [40]. In the lights of all these findings, it can be said that silver nitrate has different cytotoxic and apoptotic effects on several cancer cells.

In conclusion, we preferred to silver nitrate $\left(\mathrm{AgNO}_{3}\right)$ as silver compound, which is for testing cytotoxicity and apoptotic effects. The previous studies have suggested that silver nitrate has anticancer and apoptotic potential in various cell lines. The our work has revealed that silver nitrate has a high cytotoxic potential at low concentrations on MCF7 human breast carcinoma cells and the apoptosis proportion of cells was increased by treatment of silver nitrate in MCF7 human breast carcinoma cells depolarizing mitochondrial membrane potential. These findings demonstrate that silver nitrate could be used as a pharmaceutical agent against breast cancers.

\section{Funding}

This research did not receive any specific grant from funding agencies in the public, commercial, or not-forprofit sectors.

\section{Acknowledgements}

We thank to Medical Plants, Drugs and Scientific Research Center for cell culture studies at Anadolu University.This article was presented as a abstract poster at the EACR-Sponsored 2nd Anticancer Agents Congress \& 5 th Multidisciplinary Cancer Research Congress between 23rd-27th of April 2014.

\section{References}

1. Simstein, R., Burow, M., Parker, A., Weldon, C., Beckman, B. Apoptosis, chemoresistance and breast cancer: Insights from the MCF7 cell model system. Experimental Biology and Medicine, 2003;28, pp. 995-1003. https://doi. org/10.1177/153537020322800903

2. Syam, S., Bustamam, A., Abdullah, R., Sukari, M.A., Hashim, N.M., Ghaderian, M., Rahmani, M., Mohan, S., Abdelwahab, S.I., Ali, H.M. B- Mangostin induces p53-dependent G2/M cell cycle arrest and apoptosis through ROS mediated mitochondrial pathway and NfkB suppression in MCF7 cells. Journal of Functional Foods, 2014; 6, pp. 290-304. https://doi.org/10.1016/j.jff.2013.10.018

3. Carvalho, M.A., Paiva, R.E.F., Bergamini, F.R.G., Gomes, A.F., Gozzo, F.C., Lustri, W.R., Formiga, A.L.B., Shishido,
S.M., Ferreira, C.V., Corbi, P.P. A silver complex with tryptophan: Synthesis, structural characterization, DFT studies and antibacterial and antitumor assays in vitro. Journal of Molecular Structure, 2013;1031, pp. 125-131. https://doi.org/10.1016/j.molstruc.2012.07.044

4. Gurunathan, S., Han, J.W., Dayem, A.A., Eppakayala, V., Park, J.H., Cho, S.-G., Lee, K.J., Kim, J.-H. Green synthesis of anisotropic silver nanoparticles and its potential cytotoxicity in human breast cancer cells (MCF-7). Journal of Industrial Engineering Chemistry, 2013;19, pp. 1600-1605. https://doi. org/10.1016/j.jiec.2013.01.029

5. Medvetz, D.A., Hindi, K.M., Panzner, M.J., Ditto, A.J., Yun, Y.H., Youngs, W.J. Anticancer activity of Ag(I) n-heterocyclic carbene complexes derived from 4,5-dichloro-1h-imidazole. Metal Based Drugs, 2008: 384010, p. 2008. http://dx.doi. org/10.1155/2008/384010

6. Siciliano, T.J., Deblock, M.C., Hindi, K.M., Durmus, S., Panzner, M.J., Tessier, C.A., Youngs,W.J. Synthesis and anticancer properties of gold(I) and silver(I) N-heterocyclic carbene complexes. Journal of Organometalic Chemistry, 2011;696, pp. 1066-1071. https://doi.org/10.1016/j. jorganchem.2010.10.054

7.Ahmad, S., Isab, A.A., Ali, S., Al-Arfaj, A.R. Perspectives in bioinorganic chemistry of some metal based therapeutic agents. Polyhedron, 2006;25, pp. 1633-1645. https://doi. org/10.1016/j.poly.2005.11.004

8. Kolesarova, A., Capcarova, M., Sirotkin, A.V., Medvedova, M., Kovacik, J. In vitro assessment of silver effect on porcine ovarian granulosa cells. Journal of Trace Element Medicine Biology, 2011;25, pp. 166- 170. https://doi.org/10.1016/j. jtemb.2011.05.002

9. Sankar, R., Karthik, A., Prabu, A., Karthik, S., Shivashangari, K.S., Ravikumar, V. Origanum vulgare mediated biosynthesis of silver nanoparticles for its antibacterial and anticancer activity. Colloide Surface B, 2013;108, pp. 80-84,. https:// doi.org/10.1016/j.colsurfb.2013.02.033

10. Arora, S., Jain, J., Rajwade, J.M., Paknikar, K.M. Cellular responses induced by silver nanoparticles: In vitro studies. Toxicology Letters, 2008;179, pp. 93-100. https://doi. org/10.1016/j.toxlet.2008.04.009

11. Foldbjerg, R., Olesena, P., Hougaard, M., Dang, D.A., Hoffmann, H.J., Autrup, H. PVP-coated silver nanoparticles and silver ions induce reactive oxygen species, apoptosis and necrosis in THP-1 monocytes. Toxicology Letters, 2009;190, pp. 156-162.https://doi.org/10.1016/j.toxlet.2009.07.009

12. Cavicchioli, M., Massabni, A.C., Heinrich, T.A., Costa-Neto, C.M., Abrao, E.P., Fonseca, B.A., Castellano, E.E., Corbi, P.P., Lustri, W.R., Leite, C.Q. Pt(II) and Ag(I) complexes with acesulfame: Crystal structure and a study of their antitumoral, antimicrobial and antiviral activities. Journal of Inorganic Biochemistry, 2010;104, pp. 533-540.https:// doi.org/10.1016/j.jinorgbio.2010.01.004

13. Cuin, A., Massabni, A.C., Pereira, G.A., Leite, C.Q., Pavan, F.R., Sesti-Costa, R., Heinrich, T.A., Costa-Neto, C.M. 6-Mercaptopurine complexes with silver and gold ions: Anti-tuberculosis and anti-cancer activities. Biomedicine\&Pharmacotherapy, 2011;65, pp. 334-338. https://doi.org/10.1016/j.biopha.2011.04.012

14. Greulich, C., Diendorf, J., Gessmann, J., Simon, T., Habijan, T., Eggeler, G., Schildhauer, T.A., Epple, M., Köller, M. Cell type-specific responses of peripheral blood mononuclear cells to silver nanoparticles. Acta Biomaterialia, 2011;7, pp. 3505-3514. https://doi.org/10.1016/j.actbio.2011.05.030

15. Banti, C.N., Giannoulis, A.D., Kourkoumelis, N., Owczarzak, A.M., Poyraz, M., Kubicki, M., Charalabopoulos, K., Hadjikakou, S.K. Mixed ligand-silver(I) complexes with anti-inflammatory agents which can bind to lipoxygenase 
and calf-thymus DNA, modulating their function and inducing apoptosis. Metallomics, 2012; 4, pp. 545-560. https://doi.org/10.1039/c2mt20039b

16. Cotter, T.G. Apoptosis and cancer: the genesis of a research field. Nature Review Cancer, 2009; 9, pp. 501-507. https:// doi.org/10.1038/nrc2663

17. Yang, L. Disfunction of the apoptotic pathway in cancer cells. Chapter 1, Application of Apoptosis to Cancer Treatment, 2005, 1-28.

18. Gopinath, P., Gogoi, S.K., Sanpui, P., Paul, A., Chattopadhyay, A., Ghosh, S.S. Signaling gene cascade in silver nanoparticle induced apoptosis. Colloids and Surfaces B, 2010;77, pp. 240-245. https://doi.org/10.1016/j.colsurfb.2010.01.033

19. Li, P.W., Kuo, T.H., Chang, J.H., Yeh, J.M., Chan, W.H. Induction of cytotoxicity and apoptosis in Mouse blastocysts by silver nanoparticles. Toxicology Letters, 2010;197: 82-87. https://doi.org/10.1016/j.toxlet.2010.05.003

20. Lowe, S.W., Lin, A.W. Apoptosis in cancer. Carcinogenesis, 2000;21, pp. 485-495. https://doi.org/10.1093/ carcin/21.3.485

21. Indran, I.R., Tufo, G., Pervaiz, S., Brenner, C. Recent advances in apoptosis, mitochondria and drug resistance in cancer cells. Biochimica et Biophysica Acta, 2011;1807, pp.735-745. https://doi.org/10.1016/j.bbabio.2011.03.010

22. Ly, J.D., Grub, D.R., Lawen, A. The mitochondrial membrane potential $(\Delta \psi \mathrm{m})$ in apoptosis; an update. Apoptosis, 2003;8, pp. 115-128. https://doi.org/10.1023/A:1022945107762

23. Kutlar, A.I., Erkaya, S., Kosan I. Bartolin kisti ve absesinin gümüş nitrat ile tedavisi. Türkiye Klinikleri Gynecology Obstetrics, 1999; 9(4), p. 263-5.

24. Müller, G., Kramer, A. Biocompatibility index of antiseptic agents by parallel assessment of antimicrobial activity and cellular cytotoxicity. Journal of Antimicrobial Chemotherapy, 2008;61 pp. 1281-1287. https://doi.org/10.1093/jac/dkn125

25. Park, M.V., Neigh, A.M., Vermeulen, J.P., de la Fonteyne, L.J., Verharen, H.W., Briede, J.J., van Loveren, H., de Jong, W.H. The effect of particle size on the cytotoxicity, inflammation, developmental toxicity and genotoxicity of silver nanoparticles. Biomaterials, 2011;32, pp. 9810-9817. https://doi.org/10.1016/j.biomaterials.2011.08.085

26. Kaba, S.I., Egorova, E.M. In vitro studies of the toxic effects of silver nanoparticles on HeLa and U937 cells. Nanotechnology, Science, Applications, 2015;8, pp. 19-29. https://doi.org/10.2147/NSA.S78134

27. Krishnaraj, C., Muthukumaran, P., Ramachandran, R., Balakumaran, M.D., Kalaichelvan, P.T. Acalypha indica Linn: Biogenic synthesis of silver and gold nanoparticles and their cytotoxic effects against MDA-MB-231, human breast cancer cells. Biotechnology Reports, 2014;4, pp. 42-49. https://doi.org/10.1016/j.btre.2014.08.002

28. Miura, N., Shinohara, Y. Cytotoxic effect and apoptosis induction by silver nanoparticles in HeLa cells. Biochemical and Biophysical Research Communications, 2009;390, pp. 733-737. https://doi.org/10.1016/j.bbrc.2009.10.039

29. Koch, M., Kiefer, S., Cavelius, C., Kraegeloh, A. Use of a silver ion selective electrode to assess mechanisms responsible for biological effects of silver nanoparticles. Journal of Nanoparticle Research, 2012;14, pp. 646. https:// doi.org/10.1007/s11051-011-0646-y

30. Foldbjerg, R., Dang, D.A., Autrup, H. Cytotoxicity and genotoxicity of silver nanoparticles in the human lung cancer cell line, A549. Archives of Toxicology, 2011;85, pp. 743750. https://doi.org/10.1007/s00204-010-0545-5

31. Yamazaki, T., Yamazaki, A., Hibino, Y., Chowdhury, S.A., Yokote, Y., Kanda, Y., Kunii, S., Sakagami, H., Nakajima, H., Shimada, J. Biological impact of contact with metals on cells. In Vivo, 2006;20, p. 605-611.
32.Van der Zande, M., Undas, A.K., Kramer, E., Monopoli, M.P., Peters, R.J., Garry, D., Antunes Fernandes, E.C., Hendriksen, P.J., Marvin, H.J., Peijnenburg, A.A., Bouwmeester, H. Different responses of Caco-2 and MCF-7 cells to silver nanoparticles are based on highly similar mechanisms of action. Nanotoxicology, 2016;0(10), pp.1431-1441. https:// doi.org/10.1080/17435390.2016.1225132

33. Kaplan, A., Ciftci Akalin, G., Kutlu, H.M. The apoptotic and genomic studies on A549 cell line induced by silver nitrate. Tumor Biology, 2017;39(4), pp.1-12,. https://doi. org/10.1177/1010428317695033

34. Kaplan, A., Ciftci Akalin, G., Kutlu, H.M. Cytotoxic, antiproliferative and apoptotic effects of silver nitrate against H-ras transformed 5RP7. Cytotechnology, 2016;68(5), pp.1727-35. https://doi.org/10.1007/s10616-015-9922-5

35. Nagy, G., Turani, M., Kovacs, K.E., Banfalvi, G. Chromatin changes upon silver nitrate treatment in human keratinocyte HaCaT and K562 erythroleukemia cells. Cellular Effects of Heavy Metals 2011. pp. 195-217,. https:// doi.org/10.1007/978-94-007-0428-2_9

36. Li, S.-X., Chen, Y.-F., Lu, Y., Xü, S.-H., Liao, B.-L. Synthesis, fluorescence, and anticancer activity of silver(I) complex based on 2-hydroxyquinoxaline ligand. Inorganic and Nano-Metal Chemistry, 2020; Vol. 50, No. 4, p. 315-320.

37. Carvalho, M.F.N.N., Rego, A.M.B. de., Galveo, A.M., Herrmann, R., Marques, F. Search for cytotoxic compounds against ovarian cancer cells: Synthesis, characterization and assessment of the activity of new camphor carboxylate and camphor carboxamide silver complexes. Journal of Inorganic Biochemistry, 2018:Vol 188, p. 88-95.

38. Tamayo, L.V., Santos, A.F., Ferreira, I.P., Santos, V.G., Lopes, M.T.P., Beraldo, H. Silver(I) complexes with chromonederived hydrazones: investigation on the antimicrobial and cytotoxic effects. Biometals, 2017;30:379-392.

39. Chen, X., Yang, Q., Chen, J., Zhang, P., Huang, Q., Zhang, X., Yang, L., Xu, D., Zhao, C., Wang, X., Liu, J. Inhibition of Proteasomal Deubiquitinase by Silver Complex Induces Apoptosis in Non-Small Cell Lung Cancer Cells. Cellular Physiology and Biochemistry, 2018;49:780-797.

40. Radko, L., Stypuła-Trebas, S., Posyniak, A., Zyro, D., Ochocki, J. Silver(I) Complexes of the Pharmaceutical Agents Metronidazole and 4-Hydroxymethylpyridine: Comparison of Cytotoxic Profile for Potential Clinical Application. Molecules, 2019; 24, p. 1949; doi:10.3390/ molecules24101949

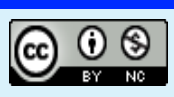

This work is licensed under a Creative Commons AttributionNon Commercial 4.0 International License. 